\title{
Study on Microstructure and Mechanical Properties of Al-Mg-Si- Cu Aluminium Alloy with High Ductility
}

\author{
Guanxia Xue ${ }^{1}$, Gu Zhong ${ }^{1, *}$, Shipeng Lin ${ }^{1}, H u$-Tian $\mathrm{Li}^{2}$, Xinghui Gui ${ }^{1}$, and Lei Zhang ${ }^{3,4}$ \\ ${ }^{1}$ Chinalco Materials Application Research Institute Co., Ltd., Suzhou Branch, Suzhou 215026, China \\ ${ }^{2}$ Chinalco Materials Application Research Institute Co., Ltd., Beijing 102209, China \\ ${ }^{3}$ Biomanufacturing Center, Department of Mechanical Engineering, Tsinghua University, Beijing 100084, China \\ ${ }^{4}$ Biomanufacturing and Rapid Forming Technology Key Laboratory of Beijing, Beijing 100084, China
}

\begin{abstract}
A new type of $\mathrm{Al}-\mathrm{Mg}-\mathrm{Si}-\mathrm{Cu}$ aluminium alloy with high ductility was studied in the present work. The microstructure features and mechanical properties of this alloy were systematically characterized by scanning electron microscopy (SEM), electron back-scatter Diffraction (EBSD), high resolution transmission electron microscopy (HRTEM) and tensile and fatigue test. The percentage of sub-grain boundary under forging and aging process reaches up to $72 \%$ which can be attributed to the suppression of recrystallization by the nano-sized AlMnCrSi dispersoids. The combination of mechanical properties of the new alloy product in aged state showed that the ductility keeps in the range of $15 \sim 18 \%$, yield strength and tensile strength are $310 \mathrm{MPa}$ and $380 \mathrm{MPa}$ respectively, fatigue strength ranges from $130 \mathrm{MPa}$ to $135 \mathrm{MPa}$. It presents more excellent properties than commercial 6061 alloy for the nano-sized AlMnCrSi dispersoids, initial- $\beta$ " precipitates and high percentage of sub-grain boundary.
\end{abstract}

Keywords: Microstructure; Mechanical Property; Al-Mg-Si-Cu Aluminum alloy; High Ductility

\section{Introduction}

6xxx series aluminum alloys are extensively used as structural parts of vehicles due to their excellent combination of properties, such as medium strength, formability, good corrosion resistance, weldability, and low manufacture cost ${ }^{[1-3]}$. Traditional forged vehicle parts are made of commercial 6061 alloy, which possess yield strength, tensile strength and ductility up to $280 \mathrm{MPa}, \quad 320 \mathrm{MPa}, \quad 10 \%-12 \%$ respectively. In consideration of energy conservation and environmental protection, lightweight is the development trends in automotive industry. Nowadays, in order to reduce weight of the vehicle forging parts, studies focus on developing high strength aluminum alloy through alloying compositions optimization, heat treatment and processing technology ${ }^{[4-8]}$. The microstructure and mechanical properties of $\mathrm{Al}-\mathrm{Mg}-\mathrm{Si}-\mathrm{Cu}$ alloy with high manganese content are studied. The dominant strengthening precipitates comprising the needle-shaped pre- $\beta^{\prime \prime}$ or $\beta^{\prime \prime}\left((\mathrm{Al}+\mathrm{Mg})_{5} \mathrm{Si}_{6}\right.$ or $\left.\mathrm{Mg}_{5} \mathrm{Si}_{6}\right)$ and lath-shaped $\mathrm{Q}^{\prime}$ $\left(\mathrm{Al}_{3} \mathrm{Cu}_{2} \mathrm{Mg}_{9} \mathrm{Si}_{7}\right)$ phases are identified in the T6 temper. With the increase of magnesium content, $\mathrm{S}\left(\mathrm{Al}_{2} \mathrm{CuMg}\right)$ phase is promoted to precipitate to give an enhancement in strength. The yield strength of the examined alloys with high manganese content is up to $380 \mathrm{MPa}$, which is $50 \%$ higher than that of commercial 6061 alloy. It is considered that, in addition to the strengthening precipitates, Mn dispersoids generating the dispersion hardening effect and the homogeneous deformation contribute a lot to the favorable mechanical properties [9.10].

Traditional forging process of vehicle parts is relatively complicated, usually more than two-step. For example, forged hubs of 22 inches commercial vehicle of commercial 6061 alloy are produced by two-step forge and one-step spinning process ${ }^{[11]}$. However, in order to further save cost, improve fatigue resistance, and lightweight auto parts of 6xxx series aluminum alloy by using one-step forging process, developing high toughness $\mathrm{Al}-\mathrm{Mg}-\mathrm{Si}-\mathrm{Cu}$ alloy is necessary.

In this paper, a new type of $\mathrm{Al}-\mathrm{Mg}-\mathrm{Si}-\mathrm{Cu}$ aluminum alloys with high ductility was studied. The microstructure features and mechanical properties of this aluminum alloy were systematically determined by SEM, HRTEM and tensile test respectively.

\section{Experimental procedure}

\subsection{Material preparation}

The chemical composition of the new Al-Mg-Si-Cu alloy studied is listed in Table 1. The content of excess $\mathrm{Si}$ was controlled from 0.1 to 0.5 . The material was prepared as follows.

* Corresponding author: zghust@qqq.com 
Table 1. The chemical composition of the $\mathrm{Al}-\mathrm{Mg}-\mathrm{Si}-\mathrm{Cu}$ alloy used in the present work (wt.\%).

\begin{tabular}{|c|c|c|c|c|c|c|c|c|}
\hline Element & $\mathrm{Si}$ & $\mathrm{Fe}$ & $\mathrm{Mg}$ & $\mathrm{Mn}$ & $\mathrm{Cu}$ & $\mathrm{Ti}$ & $\mathrm{Cr}$ & $\mathrm{Al}$ \\
\hline Content & 0.746 & 0.141 & 0.73 & 0.653 & 0.427 & 0.024 & 0.268 & $\mathrm{Bal}$ \\
\hline
\end{tabular}

(i) The billets of this new alloys were prepared experimentally by direct-chill (DC) casting, which was of $154 \mathrm{~mm}$ in diameter and $2500 \mathrm{~mm}$ in length. All billets were machined to make samples with $130 \mathrm{~mm}$ in diameter and $300 \mathrm{~mm}$ in length.

(ii) In order to eliminate elemental microsegregation and form $\mathrm{Mn}$ and $\mathrm{Cr}$ containing dispersoids homogeneously, the homogenization treatment at $560^{\circ} \mathrm{C}$ for $5 \mathrm{~h}$ subsequently air-cooled was carried out for these samples.

(iii) After homogenization treatment, samples were hot forged at $450^{\circ} \mathrm{C} \sim 500^{\circ} \mathrm{C}$ to make $120 \mathrm{~mm}$ thick plates with the reduction ratio of $60 \%$.

(iv) The forged plates were solution treated at $560^{\circ} \mathrm{C}$ for $3 \mathrm{~h}$ and quenched into water at room temperature. The subsequent aging for a short-time was performed at $160^{\circ} \mathrm{C} \sim 170^{\circ} \mathrm{C}$ for $2 \mathrm{~h} \sim 3 \mathrm{~h}$ in an air furnace.

\subsection{Characterization}

Microstructural observation of the studied Al-Mg-Si$\mathrm{Cu}$ alloy was performed by using a $15 \mathrm{kV}$ JSM-6480 type scanning electron microscope (SEM) and the type of intermetallic phases was identified by energy dispersive system (EDS). The effect of homogenization treatment on the percentage of sub-grain boundary was determined by examining hot forged specimens using electron back-scatter diffraction (EBSD) technique. The surface of the examined specimens was mechanical polished and electrochemical polishing sequentially. The experimental data were collected using a JSM-6480 type scanning electron microscope operating at $25 \mathrm{kV}$ with a TSL orientation imaging system. OIM analysis 4.6 software was used to analyze the EBSD map. The scanned area was typically $100 \mathrm{um} \times 240 \mathrm{um}$ with a step size of $0.8 \mathrm{um}$. At least three different areas were selected and the reported results were the average values. The morphology and distribution of nano-precipitates of AlMnCrSi dispersoids during the homogenization annealing and forged process and aging treatment were investigated using transmission electron microscopy (TEM), JEOL-2100F. The morphology and distribution of aged precipitates were investigated by using high resolution transmission electron microscopy (HRTEM) with the symmetric condition along $\mathrm{Al}(001)$ axes. Thin foils for TEM study were prepared by first mechanical polishing to a thin foil about $80 \mathrm{um}$ and then electropolishing in a methanol solution mixed with $30 \%$ nitric acid and $70 \%$ alcohol. To evaluate the strength and ductility of the examined alloys, tensile tests were carried out. The tensile tests were conducted on an Instron 5967 30KN Materials testing machine operated at a constant crosshead speed with an initial strain rate of $5 \times 10^{-4} \mathrm{~s}^{-1}$. The tensile specimens were machined perpendicular to the forging direction as GB/T228.1-
2010 standard with the gauge length of $50 \mathrm{~mm}$. The schematic of tensile specimen is depicted in Fig. 1(a). As for tensile test, three specimens were tested and the average value was taken. High cycle fatigue (HCF) tests were obtained for constant amplitude loading with sinusoidal wave forms. The fatigue life tests (S-N curves) were carried out on specimens (midsection diameter $5.0 \mathrm{~mm}$ ). These tests were performed at $\mathrm{R}=-1$ using MTS Landmark 370.10 fatigue testing machine with a frequency of $60 \mathrm{~Hz}$. The S-N curves were measured in laboratory air. The schematic of fatigue specimen is depicted in Fig. 1(b). The final surface finish of the fatigue specimen after machining requires 0.32 and no further operation is carried out.

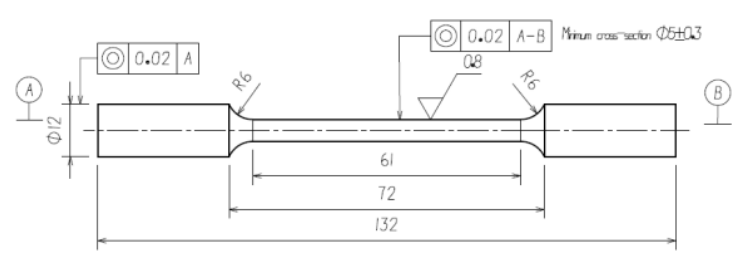

(a)

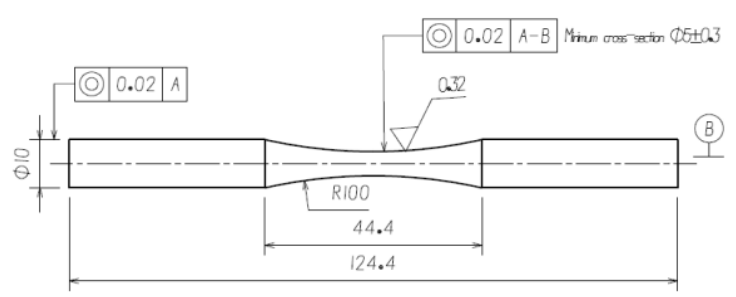

(b)

Fig.1.Schematics of the test specimens

(a) tensile specimen; (b) fatigue specimen.

\section{Results and discussion}

\subsection{Microstructural characterization}

The as cast microstructures of the new $\mathrm{Al}-\mathrm{Mg}-\mathrm{Si}-\mathrm{Cu}$ alloy is shown in Fig.2. Substantial distinct intermetallic constituents are observed in the $\alpha$-Al inter-dendritic regions, forming almost continuous network. Fig. 3 shows higher magnification microstructure of the different intermetallic constituents, which contain three intermetallic phases: $\mathrm{Mg}_{2} \mathrm{Si}, \mathrm{Al}(\mathrm{Fe}, \mathrm{Mn}, \mathrm{Cr}) \mathrm{Si}$ and $\mathrm{AlCuMgSi}$. They were identified by a combination of morphology and EDS analysis (Table 2). The $\mathrm{Al}(\mathrm{Fe}, \mathrm{Mn}, \mathrm{Cr}) \mathrm{Si}$ intermetallic compound, which commonly known as $\alpha$-phase, with a typical feathery structure or lamellar morphology, is the dominant phase in this new $\mathrm{Al}-\mathrm{Mg}-\mathrm{Si}-\mathrm{Cu}$ alloy. $\mathrm{Mg}_{2} \mathrm{Si}$ phase appears as needle-shaped or Chinese script-like structure. A small

Corresponding author: zghust@qq.com 
quantity of $\mathrm{AlCuMgSi}$ phases with round or oval-shaped morphology were observed to form as separate phase in the inter-dendritic regions.

In as cast $\mathrm{Al}-\mathrm{Mg}-\mathrm{Si}-\mathrm{Cu}$ alloys, the remaining content of $\mathrm{Si}$ which does not form intermetallic compound $\mathrm{Mg}_{2} \mathrm{Si}$ is defined as excess Si. Generally, the more excess $\mathrm{Si}$ the alloy contains, the higher tensile strength and yield strength will be ${ }^{[9]}$. In our opinion, a small amount of excess $\mathrm{Si}$, ranging from 0.1 to $0.5 \mathrm{wt} \%$, is favorable for improving the ductility of the $\mathrm{Al}-\mathrm{Mg}-$ $\mathrm{Si}-\mathrm{Cu}$ alloy while ensuring the tensile strength and yield strength of the alloy. It can be found that, in Fig.3, in as cast microstructure of the $\mathrm{Al}-\mathrm{Mg}-\mathrm{Si}-\mathrm{Cu}$ alloy, two intermetallic phases with excess $\mathrm{Si}$ are $\mathrm{Al}$ (Fe,Mn, $\mathrm{Cr}$ )Si and $\mathrm{AlCuMgSi}$. In Table. 2, based on the EDS analysis, the average composition of the $\mathrm{Al}(\mathrm{Fe}, \mathrm{Mn}, \mathrm{Cr}) \mathrm{Si}$ phase are 72.33 wt.\% $\mathrm{Al}, 20.78$ wt.\% $(\mathrm{Mn}+\mathrm{Cr}+\mathrm{Fe})$, and 6.89 wt. $\% \mathrm{Si}$. It is close to $\alpha-\mathrm{Al}_{15}(\mathrm{Fe}, \mathrm{Mn})_{3}-\mathrm{Si}_{2}$ as reported in literature $^{[11]}$. The AlCuMgSi phase has a variable copper content from 5.64 to 10.01 mass\% depending on $\mathrm{Mg} / \mathrm{Si}$ ratio.

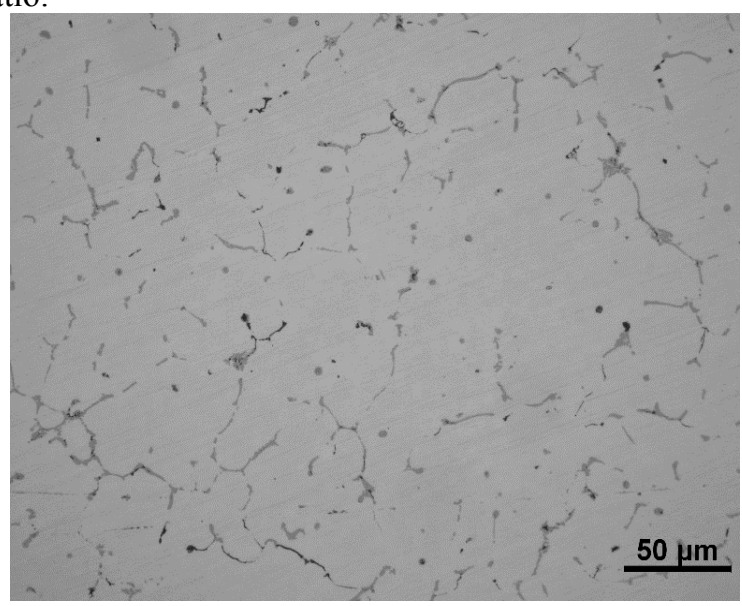

Fig.2. Microstructure of the new $\mathrm{Al}-\mathrm{Mg}-\mathrm{Si}-\mathrm{Cu}$ alloy in as-cast state

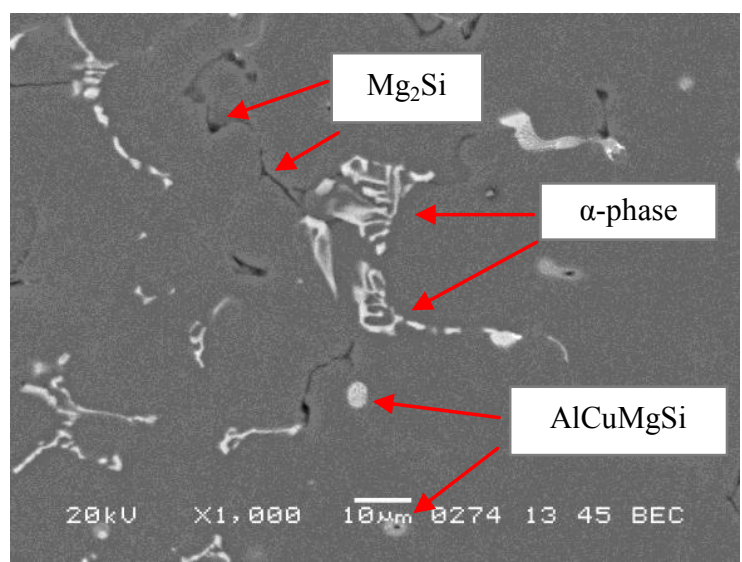

Fig.3. Higher magnification microstructure of the new $\mathrm{Al}-\mathrm{Mg}-$ $\mathrm{Si}-\mathrm{Cu}$ alloy showing the different morphology of intermetallic constituents.

Table 2. Composition of the experimentally observed intermetallic phases in Fig. 3 (wt.\%).

\begin{tabular}{|l|l|l|l|l|l|l|l|}
\hline Phase & $\mathrm{Mg}$ & $\mathrm{Si}$ & $\mathrm{Cu}$ & $\mathrm{Cr}$ & $\mathrm{Mn}$ & $\mathrm{Fe}$ & $\mathrm{Al}$ \\
\hline
\end{tabular}

\begin{tabular}{|c|c|c|c|c|c|c|c|}
\hline \multirow{2}{*}{$\mathrm{Mg}_{2} \mathrm{Si}$} & 8.44 & 11.77 & - & - & - & - & 79.79 \\
\cline { 2 - 8 } & 8.99 & 12.74 & 0.49 & - & - & - & 77.78 \\
\hline \multirow{3}{*}{$\alpha-p h a s e$} & 1.00 & 7.01 & 1.21 & 2.22 & 8.00 & 9.20 & 71.37 \\
\cline { 2 - 8 } & 0.96 & 3.40 & 0.99 & 1.10 & 5.76 & 6.57 & 81.22 \\
\hline \multirow{2}{*}{ AlCuMgSi } & 4.17 & 10.57 & 8.14 & - & - & - & 77.12 \\
\cline { 2 - 8 } & 2.00 & 8.80 & 10.01 & - & - & - & 79.19 \\
\hline
\end{tabular}

The microstructure of this new alloy after homogenization annealing is shown in Fig. 4. The majority of $\mathrm{Mg}_{2} \mathrm{Si}$ and the all of $\mathrm{AlCuMgSi}$ phases were dissolved into the $\mathrm{Al}$ matrix. It can be seen from Fig. 5 that there was a fragmentation and spheroidization of the $\alpha$-phase with distribution along boundaries after homogenization annealing.

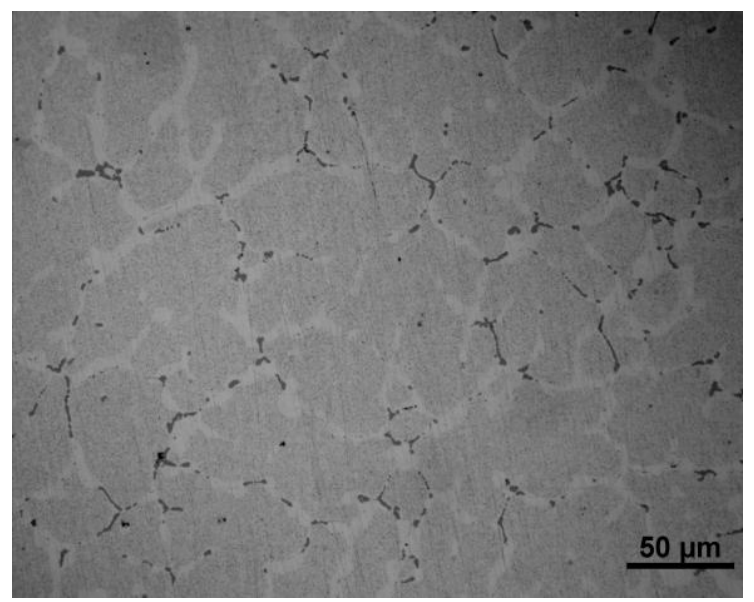

Fig.4. Microstructure of the new $\mathrm{Al}-\mathrm{Mg}-\mathrm{Si}-\mathrm{Cu}$ alloys after homogenization annealing at $560^{\circ} \mathrm{C}$ for $5 \mathrm{~h}$.

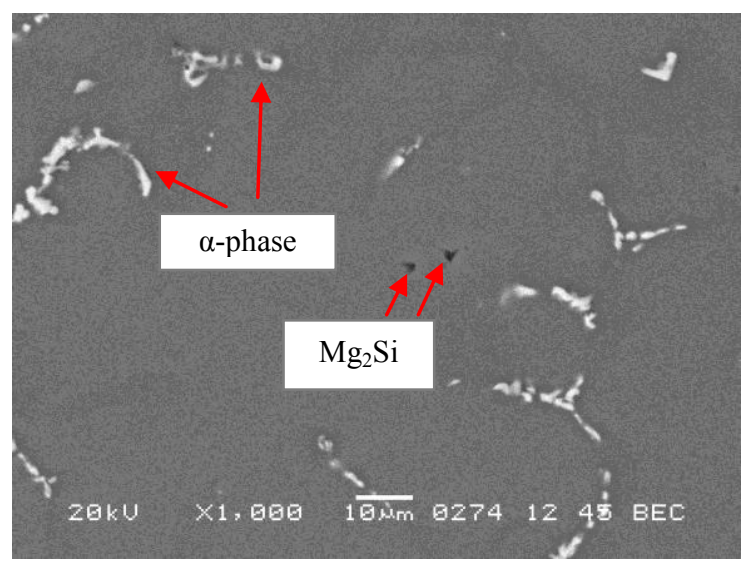

Fig.5. Higher magnification microstructure of the new $\mathrm{Al}-\mathrm{Mg}-$ $\mathrm{Si}-\mathrm{Cu}$ alloy after homogenization annealing at $560^{\circ} \mathrm{C}$ for $5 \mathrm{~h}$ showing an obvious fragments of $\mathrm{a}-\mathrm{Al}(\mathrm{Fe}, \mathrm{Mn}, \mathrm{Cr}) \mathrm{Si}$ phase.

The EBSD micrograph of the new $\mathrm{Al}-\mathrm{Mg}-\mathrm{Si}-\mathrm{Cu}$ alloys after hot forging with homogenization heating rate $7^{\circ} \mathrm{C} / \mathrm{min}$ is shown in Fig.6. The different color contrast in the EBSD maps is corresponding to different grain orientation. The severely fragmented and elongated subgrains like thin ribbon are observed. Through statistical analysis, the percentage of sub-grain boundary of the 
new $\mathrm{Al}-\mathrm{Mg}-\mathrm{Si}-\mathrm{Cu}$ is $72 \%$, which is $20 \%$ higher than that of 6061 alloy. The higher percentage of sub-grain boundary, the higher ductility of the new $\mathrm{Al}-\mathrm{Mg}-\mathrm{Si}-\mathrm{Cu}$ alloy will be. It is responsible for the highly uniform precipitation and dispersion characteristics of dispersoids during homogenization annealing in the new $\mathrm{Al}-\mathrm{Mg}-\mathrm{Si}-$ $\mathrm{Cu}$ alloy with appropriate amount of excess $\mathrm{Si}$ (in the range of $0.1-0.5 w t . \%)$, which play a critical role in preventing the nucleation of recrystallized grains during forging process and solution treatment ${ }^{[12]}$. The uniform precipitation dispersoids during homogenization annealing in the new $\mathrm{Al}-\mathrm{Mg}-\mathrm{Si}-\mathrm{Cu}$ alloy with appropriate amount of excess $\mathrm{Si}$ will be illustrated with HRTEM observation in detail.

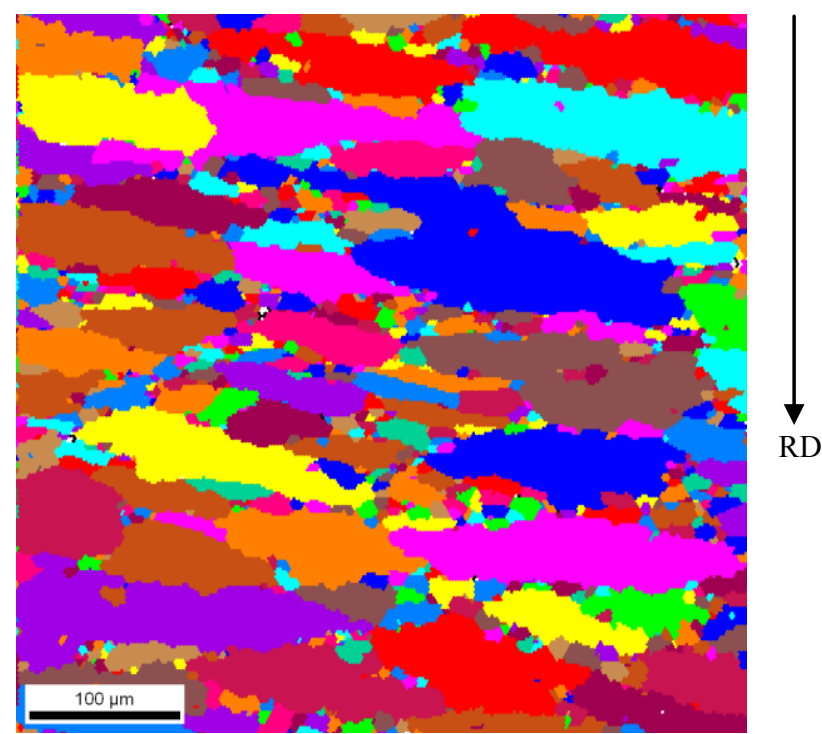

Fig.6. EBSD micrographs of the new $\mathrm{Al}-\mathrm{Mg}-\mathrm{Si}-\mathrm{Cu}$ alloy after hot forging process.

\subsection{HRTEM observations in material preparation}

Fig. 7a shows a TEM bright-field images obtained from this new $\mathrm{Al}-\mathrm{Mg}-\mathrm{Si}-\mathrm{Cu}$ alloy homogenized at $560^{\circ} \mathrm{C}$ for $5 \mathrm{~h}$ and subsequently air-cooled. It can be found that numerous rod-like or cube-like nano-precipitates of AlMnCrSi dispersoids in size of $100-500 \mathrm{~nm}$, distribute dispersedly in Al matrix. Fig. 7b shows a TEM brightfield images obtained from this new $\mathrm{Al}-\mathrm{Mg}-\mathrm{Si}-\mathrm{Cu}$ alloy after forging process. During the forging process, the grains are broken into small ones relatively. Simultaneously, the size and distribution of the nanosized AlMnCrSi dispersoids also change. It can be seen, that most of the AlMnCrSi dispersoids locate in grain boundary and its size reduce to $50-200 \mathrm{~nm}$. The effect of nano-sized AlMnCrSi dispersoids on pinning grain boundary is better for preventing the nucleation of recrystallized grains during forging process and make grains smaller. Therefore, the percentage of sub-grain of the new $\mathrm{Al}-\mathrm{Mg}-\mathrm{Si}-\mathrm{Cu}$ alloys after forging process is higher than the percentage of sub-grain of 6061 alloy. Fig. 7c shows a TEM bright-field images obtained from this new $\mathrm{Al}-\mathrm{Mg}-\mathrm{Si}-\mathrm{Cu}$ alloy after aging treatment. During the aging treatment, the size and shape of the remained nano-sized $\mathrm{AlMnCrSi}$ dispersoids also change simultaneously. It can be seen, that the shape of the $\mathrm{AlMnCrSi}$ dispersoids has become rounded and its size reduce to $20-100 \mathrm{~nm}$ furtherly.

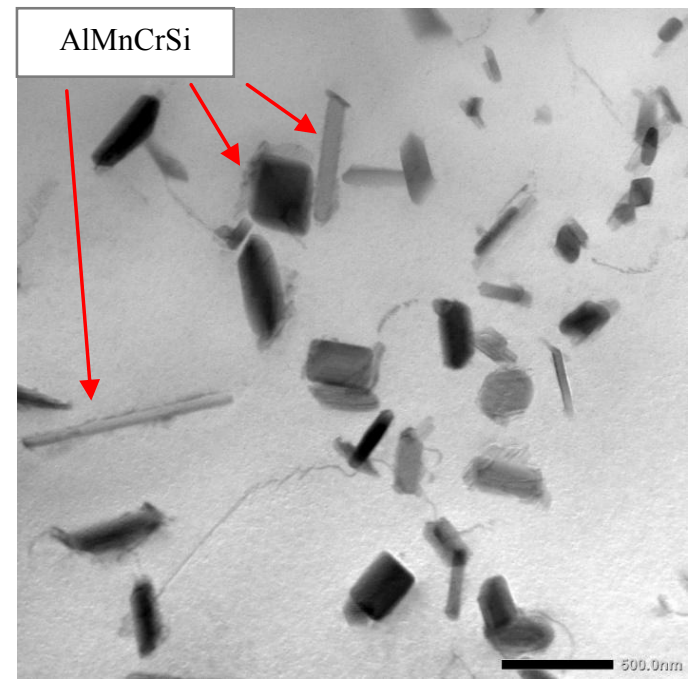

(a)

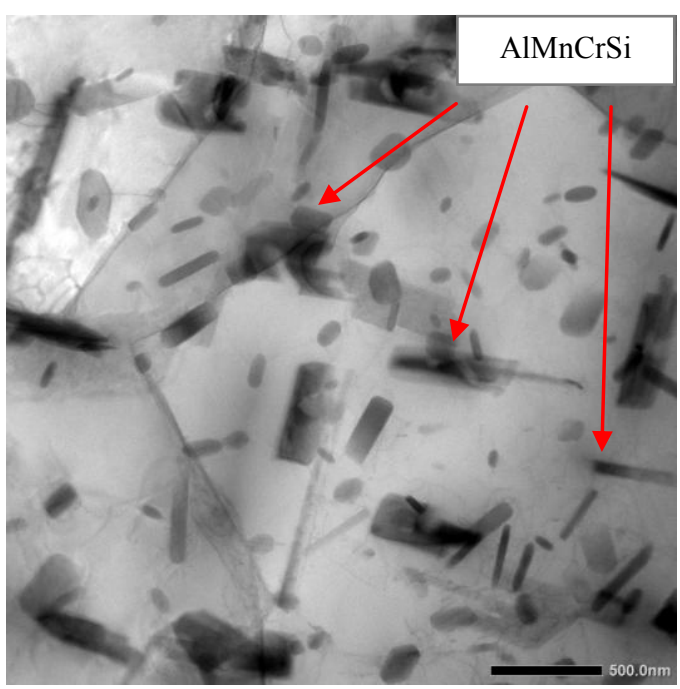

(b)

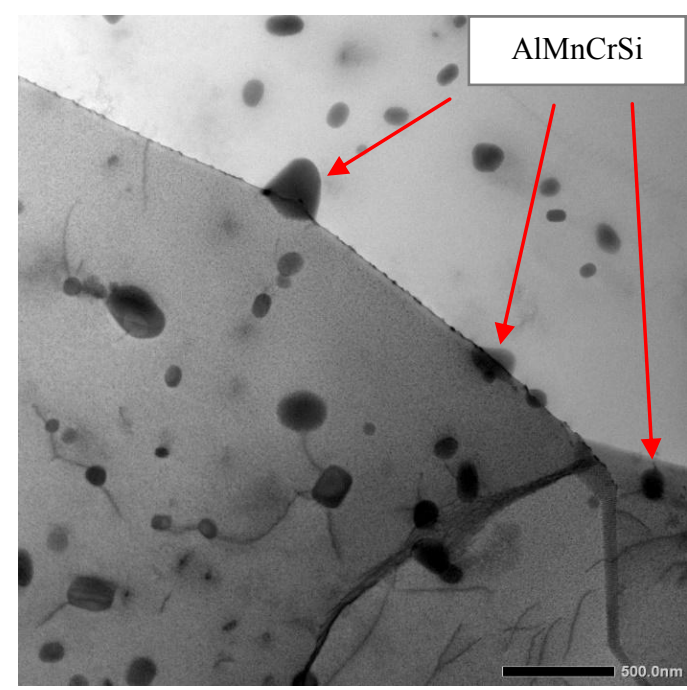


(c)

Fig. 7. TEM micrographs of AlMnCrSi dispersoids in the new Al-Mg-Si-Cu alloy: (a) dispersion distribution after homogenization annealing; (b) uniform distribution in the matrix after forge process; (c) uniform distribution in the matrix after aging treatment.

Commonly, the precipitation sequence in the matrix of $6 \mathrm{xxx}$ series alloys after aging treatment is as follows: Supersaturated solid solution - clusters - GP zones and initial- $\beta$ " - pre- $\beta$ ", $\beta$ ” and Q" - Q' (partially coherent version of $Q$ ) and $\beta$ (or $\beta^{\prime}$ ) $-Q$ and $\beta$. Meanwhile, for $\mathrm{Al}-\mathrm{Mg}-\mathrm{Si}-\mathrm{Cu}$ alloys, two types of strengthening phases, needle-shaped pre- $\beta$ " and lath-shaped Q' precipitates, would precipitate in the T6 temper at $170-180^{\circ} \mathrm{C}$ $[10,11,15,16]$. However, the precipitated phase of this new $\mathrm{Al}-\mathrm{Mg}-\mathrm{Si}-\mathrm{Cu}$ alloy taken an aging of low-temperature and shot-time treatment is different compared to T6 temper of 6061 alloy.

Fig. 8(a) shows a TEM bright-field images obtained from this new $\mathrm{Al}-\mathrm{Mg}-\mathrm{Si}-\mathrm{Cu}$ alloy aged at $160^{\circ} \mathrm{C} \sim 170^{\circ} \mathrm{C}$ for $2 \mathrm{~h} \sim 3 \mathrm{~h}$. A great number of aged nano-precipitates, AlMnCrSi dispersoids, are delineated by strain-field contrast. HRTEM micrographs further reveals only one type of strengthening phase, needle-shaped initial- $\beta$ " precipitates, whose composition is $\mathrm{Mg}_{2} \mathrm{Si}_{3} \mathrm{Al}_{6}$ (Fig. 8b). The initial- $\beta$ " precipitate is generally considered as the precursor of pre- $\beta$ " $\left((\mathrm{Al}+\mathrm{Mg})_{5} \mathrm{Si}_{6}\right)$ or $\beta "\left(\mathrm{Mg}_{5} \mathrm{Si}_{6}\right)^{[10,14-16]}$. The needle-shaped initial- $\beta$ " precipitate is oriented along the $\mathrm{Al}<001>$ direction. As shown in Fig. 8b, the cross section of aged nano-precipitates is observed making its diameter measurable accurately. The average diameter of initial- $\beta$ " precipitate is about $2-3 \mathrm{~nm}$. In addition, the needle-shaped initial- $\beta$ " precipitate oriented along the Al $<001>$ direction is also observed lying in Fig. 8b, which is nearly $8-10 \mathrm{~nm}$ length.

Furthermore, the remained nano-sized AlMnCrSi dispersoids after the aging treatment distributed dispersedly and uniformly in the grain and on the grain boundary. When the fatigue crack propagates, these AlMnCrSi dispersoids can prevent crack growth further. So, the fatigue life of the new $\mathrm{Al}-\mathrm{Mg}-\mathrm{Si}-\mathrm{Cu}$ alloy products may be improved.

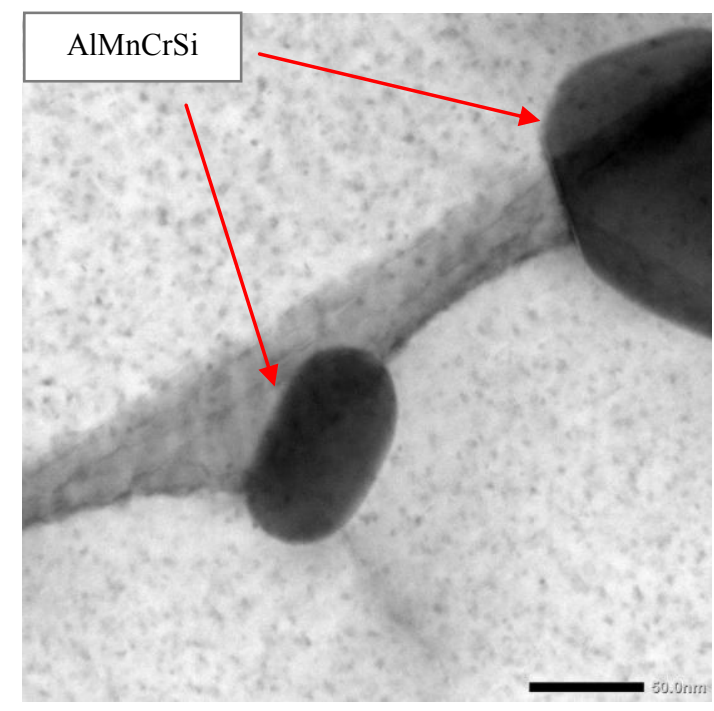

(a)

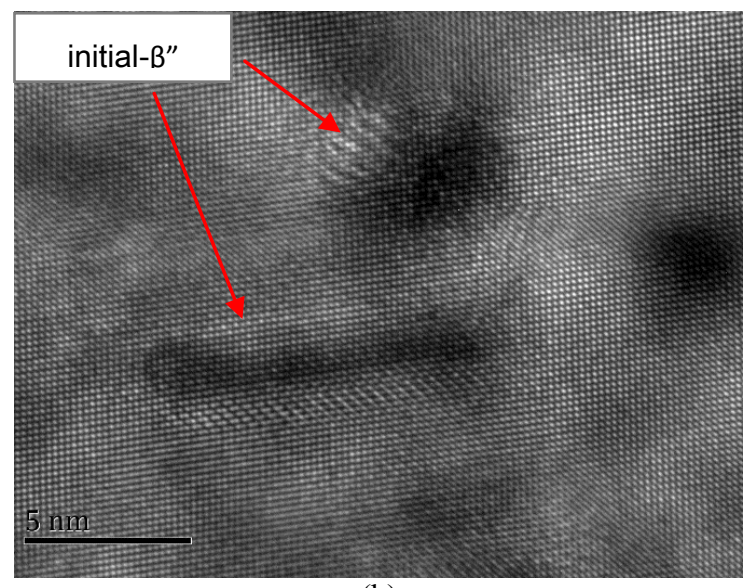

(b)

Fig. 8. TEM images of the new $\mathrm{Al}-\mathrm{Mg}-\mathrm{Si}-\mathrm{Cu}$ alloy: (a) bright-field micrograph along with [001]Al; (b) HRTEM micrographs of needle-shaped initial- $\beta$ " precipitates imaged along their axes.

\subsection{Mechanical properties}

The combination of mechanical properties of the new $\mathrm{Al}-\mathrm{Mg}-\mathrm{Si}-\mathrm{Cu}$ alloy in aged state are given in Table 3. Compared with the commercial 6061 alloy, both strength and ductility of this new alloy increase significantly. Table 3 shows that the elongation is stable in the range from $15 \%$ to $18 \%$, yield strength and tensile strength are $310 \mathrm{MPa}$ and $380 \mathrm{Mpa}$, respectively. In summary, the ductility and strength of this new Al-Mg-Si-Cu aluminum alloy are 35 percent and 11 percent higher than the commercial 6061 alloy.

The excellent ductility of this new alloy can be attributed to the uniform precipitation and dispersion characteristics of nano-sized AlMnCrSi dispersoids during homogenization annealing process and then the nano-sized AlMnCrSi dispersoids pinned the grain boundary to improve the ratio of sub-grain during the forging and heat treatment process, subsequently. As a result, the ratio of sub-grain boundary in the annealing microstructure, forging microstructure and age-state microstructure can be improved. So, the ductility of the $\mathrm{Al}-\mathrm{Mg}-\mathrm{Si}-\mathrm{Cu}$ alloy is improved while ensuring its tensile strength and yield strength. Furthermore, the needle-shaped phase of the initial- $\beta$ " precipitates during the aging treatment can further improve the ductility. Moreover, nano-sized AlMnCrSi dispersoids also can improve the fatigue life of the new $\mathrm{Al}-\mathrm{Mg}-\mathrm{Si}-\mathrm{Cu}$ alloy products as mentioned above in section 3.2.

Table 3. Mechanical properties of the new Al-Mg-Si-Cu alloys and commercial 6061 alloy

\begin{tabular}{|c|c|c|c|l|l|}
\hline \multicolumn{2}{|c|}{ Alloy } & $\begin{array}{c}\text { Ultimate } \\
\text { tensile } \\
\text { strength } \\
(\mathrm{MPa})\end{array}$ & $\begin{array}{c}\text { Yield } \\
\text { strength } \\
(\mathrm{MPa})\end{array}$ & $\begin{array}{c}\text { Elongation } \\
(\%)\end{array}$ & $\begin{array}{c}\text { Fatigue } \\
\text { strength } \\
(\mathrm{MPa})\end{array}$ \\
\hline $\begin{array}{l}\text { New } \\
\text { alloy }\end{array}$ & Test 1 & 391 & 320 & 16.0 & 135 \\
\cline { 2 - 6 } & Test 2 & 387 & 310 & 16.3 & 134 \\
\hline
\end{tabular}




\begin{tabular}{|c|c|c|c|c|}
\hline Test 3 & 385 & 312 & 18.0 & 132 \\
\hline 6061 alloy & 290 & 255 & 13.0 & 118 \\
\hline
\end{tabular}

\section{Conclusion}

1. The as cast microstructures of the new $\mathrm{Al}-\mathrm{Mg}-\mathrm{Si}-$ $\mathrm{Cu}$ alloy contain three intermetallic phases: $\mathrm{Mg}_{2} \mathrm{Si}$, $\mathrm{Al}(\mathrm{Fe}, \mathrm{Mn}, \mathrm{Cr}) \mathrm{Si}$ and $\mathrm{AlCuMgSi}$, Which present in nano-sized rounded AlMnCrSi dispersoids about 20$100 \mathrm{~nm}$ in size, and initial- $\beta$ " precipitates about 2-3 $\mathrm{nm}$ in diameter and nearly $8-10 \mathrm{~nm}$ in length respectively after solution and short time aging treatment. The percentage of sub-grain boundary of the new $\mathrm{Al}-\mathrm{Mg}-\mathrm{Si}-\mathrm{Cu}$ aluminum alloys under the forging process reach up to $72 \%$.

2. The combination of mechanical properties of the new $\mathrm{Al}-\mathrm{Mg}-\mathrm{Si}-\mathrm{Cu}$ aluminum alloys product in aged state show that the ductility is in a range from $15 \%$ to $18 \%$, yield strength and tensile strength are $310 \mathrm{MPa}$ and $380 \mathrm{MPa}$ respectively, fatigue strength is range from $130 \mathrm{MPa}$ to $135 \mathrm{MPa}$.

3. In summary, the ductility and strength of this new $\mathrm{Al}-\mathrm{Mg}-\mathrm{Si}-\mathrm{Cu}$ aluminum alloys are 35 percent and 11 percent higher than commercial 6061 alloy. The new type of $\mathrm{Al}-\mathrm{Mg}-\mathrm{Si}-\mathrm{Cu}$ aluminum alloys with high ductility can be used in forged wheel of commercial vehicle with one forging process.

This work was funded by Project 2016YFB0101603 supported by National Key Research and Development Program.

\section{References}

1. D. Gao, W. Nonferrous Met. 11, 174-176 (2019).

2. D. Maisonnette, M. Suery, D. Nelias, P. Chaudet, Mater. Sci. Eng. A, 528, 2718 (2011).

3. SK. Panigrahi, R. Jayaganthan, J Alloys Compd, 470, 285(2009).

4. H. Liu, Reaearch on Liquid Forging and Heat Treatment of High Strength and Toughness Aluminum Alloy Wheel: [D]. Harbin: Harbin Institute of Technology, 2015.

5. S.K. Panigrahi, R. Jayaganthan, J ALLOY COMPD, 470, 285-288 (2009).

6. S. Zhou, Study on fatigue characteristics and fracture behavior of high strength and high toughness $\mathrm{AlMgSiCu}$ alloy sheet: [D]. Guangxi: Guangxi University of Science and Technology, 2019.

7. D. Maisonnette, M. Suery, D. Nelias, P. Chaudet, Mater. Sci. Eng., A, 528, 2718-2724 (2011).

8. A. Loucif, R.B. Figueiredo, T. Baudin, Mater. Sci. Eng., A, 527, 4864-4869 (2010).

9. Y. Han, K. Ma, L. Li, H. Nagaumi. Mater. Des. 39, 418-424 (2012).
10. J. H. Chen, C.H. Liu, Chin. J. Nonferrous Met, 21,10(2011).

11. C. He, W. Nonferrous Met. 3, 282-283 (2018)

12. M. Murayama, K. Hono, W.F. Miao, and D.E. Laughlin, Metal. Mater. Trans. A, 32A, 239(2001).

13. Y. Han, K. Ma, H. Nagaumi, TMS, 418-424 (2012).

14. X. Wang, S. Esmaeili, D. J. Lloyd, Metal. Mater. Trans. A, 37A, 2006-2691 (2006).

15. G.C. Weatherly, A. Perovic, N.K. Mukhopadhyay, Metal. Mater. Trans. A, 32A, 213(2001).

16. J. H. Chen, E. Costan, M. A. van Huis, Q. Xu, H. W. Zandbergen, SCI. 312, 416-419 (2006). 